\title{
ANALISIS JARINGAN KOLABORASI DALAM PENCEGAHAN DAN PENANGGULANGAN HIV/AIDS: STUDI DI KABUPATEN SUBANG JAWA BARAT
}

\section{(ANALYSIS OF COLLABORATIVE NETWORK IN HIVIAIDS PREVENTION AND CONTROL: STUDY IN SUBANG REGENCY-WEST JAVA)}

\author{
Sam'un Jaja Raharja ${ }^{1 *}$ \& Dede Akhmad ${ }^{2}$ \\ ${ }^{1}$ Universitas Padjadjaran, Indonesia \\ ${ }^{2}$ Badan Perencanaan Pembangunan, Penelitian dan Pengembangan Daerah Kabupaten Subang \\ *Korespondensi penulis: harja_63@yahoo.com
}

\begin{abstract}
There is an increasing trend of people living with HIV/AIDS (PLWHA) in Subang District, a region characterized by high population mobility. Hence, this study aims to explain the factors that influence collaboration in HIV/AIDS prevention and control in Subang Regency. This study uses a latent construct of collaboration reflected by five dimensions: governance, administration, organizational authority, mutuality, and norms. This study uses quantitative methods and data collection techniques through distributing questionnaires to 72 respondents involved in HIV/AIDS prevention and prevention in Subang Regency. The selection of respondents represents government and non-government organizations based on quota sampling. Data were analyzed by Partial Least SquareStructural Equation Modeling (PLS-SEM) in the second order confirmatory factor analysis to explain the collaboration measurement model as a latent construct. The results showed that all dimensions of the collaboration construct were valid and reliable. All dimensions can be said to significantly explain the collaborative construct of HIV/AIDS prevention and care. The dimensions of governance are the most valuable factors that influence the construct of collaboration, followed by organizational autonomy, administration, mutuality, and finally norms as dimensions with the smallest contribution value to collaboration.
\end{abstract}

Keywords: governance, collaboration model, HIV/AIDS

\begin{abstract}
Abstrak
Terdapat kecenderungan peningkatan orang yang hidup dengan HIV/AIDS (ODHA) di Kabupaten Subang, sebuah wilayah yang ditandai dengan mobilitas penduduk yang tinggi. Maka penelitian ini bertujuan untuk menjelaskan faktor-faktor yang memengaruhi kolaborasi dalam pencegahan dan penanggulangan HIV/AIDS di Kabupaten Subang. Penelitian ini menggunakan konstruk laten kolaborasi yang dicerminkan oleh lima dimensi: tata kelola, administrasi, otoritas organisasi, mutualitas, dan norma. Penelitian ini menggunakan metode kuantitatif dan teknik pengumpulan data melalui penyebaran kuesioner kepada 72 responden yang terlibat dalam pencegahan dan penanggulangan HIV/AIDS di Kabupaten Subang. Pemilihan responden mewakili organisasi pemerintah dan non pemerintah berdasarkan sampling kuota. Data dianalisis dengan Partial Least Square-Structural Equation Modeling (PLS - SEM) pada analisis faktor konfirmatori orde kedua untuk menjelaskan model pengukuran kolaborasi sebagai konstruk laten. Hasil penelitian menunjukkan semua dimensi konstruk kolaborasi valid dan reliabel. Semua dimensi dapat dikatakan secara signifikan menjelaskan konstruk kolaborasi tentang pencegahan dan perawatan HIV/AIDS. Dimensi tata kelola adalah faktor yang paling bernilai yang memengaruhi konstruk kolaborasi, diikuti oleh otonomi organisasi, administrasi, mutualitas, dan terakhir norma sebagai dimensi dengan nilai konstribusi terkecil terhadap kolaborasi.
\end{abstract}

Kata kunci: Tata Kelola, Model Kolaborasi, HIV/AIDS 
Jurnal Kependudukan Indonesia | Vol. 14, No. 1, Juni 2019|29-48

\section{PENDAHULUAN}

Dewasa ini, penyebaran HIV/AIDS sudah menjadi endemik global, nasional dan lokal. Pada awal tahun 1990an HIV/AIDS dianggap sebagai penyakit orang asing atau orang yang banyak berhubungan dengan orang asing. Kasus kematian karena HIV/AIDS pertama kali muncul pada tahun 1985 dengan meninggalnya aktor Rock Hudson. Sejak saat itu masalah HIV/AIDS menjadi perhatian masyarakat dunia (global).

Kasus HIV/AIDS semakin meningkat dari tahun ke tahun. Berdasarkan data dari UNAIDS, sebanyak 36,9 juta orang dari berbagai negara hidup bersama HIV dan AIDS pada 2017 (Azanella, 2018). Pada skala regional Asia-Pasifik, Filipina merupakan negara dengan penyebaran HIV/AIDS tertinggi. Hal ini dapat dilihat dari lonjakan kasus sebanyak 4.300 pada tahun 2010 menjadi 10.500 di tahun 2017 (Yulianingsih, 2017).

Pada skala nasional/lokal Indonesia, kasus HIV/AIDS pertama kali ditemukan di Bali pada tahun 1987 (Purwaningsih \& Widayatun, 2008). Sampai dengan tahun 2017 di Indonesia sudah tercatat 280.623 jiwa hidup dengan HIV/AIDS (Kemenkes, 2018). Sampai dengan Juni tahun 2018 jumlahnya meningkat lagi menjadi 301.959 jiwa ("Hari AIDS Sedunia", 2018).

Penanganan penyebaran HIV/AIDS merupakan salah satu agenda Sustainable Development Goals (SDGs), yang targetnya harus tercapai pada tahun 2030 (Hoelman, Parhusip, Eko, Bahagijo, \& Santono, 2015:8). Agenda SDGs menetapkan target khusus yang terkait dengan Sexual and Reproductive Health and Rights (SRHR) yang mengakhiri epidemi berbagai wabah penyakit menular termasuk HIV/ AIDS (Prapti, 2015:4; Bappenas, 2017).

Penyebaran HIV/AIDS di Indonesia terus meningkat. Pada tahun 2000 penyebarannya mencapai di atas 5\% dari jumlah kelompok berisiko tinggi, yaitu pengguna jarum suntik untuk narkoba, para pekerja seks komersial, dan homoseksual (Waluyo, 2011). Penularan HIV juga terus meningkat dengan tajam. Pada tahun 2017 tercatat 48.300 kasus, meningkat $17,09 \%$ dari tahun sebelumnya. Sementara itu, pada tahun 2017 tercatat 9.280 kasus AIDS. Meskipun jumlah tersebut turun $8,54 \%$ dari tahun sebelumnya, ada kemungkinan penurunan ini bukan fakta sebenarnya karena rendahnya pelaporan kasus AIDS dari daerah (Kementerian Kesehatan, 2019).

Permasalahan HIV/AIDS merupakan fenomena gunung es. Jumlah data yang dilaporkan hanya sebagian saja dari kasus yang sebenarnya terjadi (Sanusi, 2014; Hugo, 2011). Fenomena gunung es juga terlihat dari hasil penelitian Situmorang (2006) tentang pemuda jalanan di Kota Medan yang merupakan kelompok paling rentan terhadap penyakit seksual menular (PMS). Kondisi mereka sulit dijangkau dan belum terlayani, sehingga tidak terdata dengan baik. Purwaningsih dan Widayatun (2008) juga menyatakan bahwa data mengenai kasus HIV-AIDS di Indonesia masih simpang siur. Data resmi yang dipublikasikan diperkirakan sangat jauh dari jumlah sebenarnya.

Pola penyebaran penyakit menular seksual ini mengalami pergeseran bukan hanya karena pola perilaku seks bebas, tetapi juga pengguna narkotika suntik dan penularan ibu yang mengidap HIV kepada bayi yang dikandungnya (Sucipto \& Hartoyo, 2009). Hugo (2011) mengatakan bahwa penyebaran HIV/AIDS di Indonesia tampaknya telah melalui tiga tahap. Pertama, muncul pada kelompok tertentu yang disebarkan lewat hubungan homoseksual. Pola kedua adalah menyebar melalui hubungan seks heteroseksual dan pola ketiga penyebaran lewat jarum suntik pengguna narkoba (IDU).

Pantai Utara (Pantura) merupakan bagian Provinsi Jawa Barat dengan jumlah penduduk terbesar serta angka mobilitas yang paling tinggi, karena dukungan infrastruktur jalan yang membentang dari Jawa Tengah hingga perbatasan DKI Jakarta. Infrastruktur jalan ini menyebabkan tingginya mobilitas penduduk yang diiringi dengan menyebarnya lokalisasi prostitusi di sejumlah titik. Akibatnya Pantura menjadi salah satu daerah dengan epidemi HIV/AIDS tinggi di Jawa Barat (Hidayana, 2012; Hugo, 2011; Hull, Sulistianingsih, \& Jones, 1998). Tingginya mobilitas penduduk berkorelasi dengan tingginya penyebaran HIV/AIDS. Skeldon (2000) bahkan dengan tegas menyatakan bahwa terdapat hubungan yang "nyata dan kompleks" antara mobilitas penduduk dengan penyebaran HIV/AIDS. 
Pernyataan Skeldon hampir sama dengan apa yang dikemukakan Situmorang dan Purwaningsih (2010) tentang epidemi HIV/AIDS berkaitan dengan sexually transmitted infections (STIs) sebagai masalah kesehatan di wilayah perbatasan negara. Empat provinsi dengan tingkat AIDS tertinggi adalah provinsi yang berada di perbatasan negara atau bertetangga dengan negara lain yaitu Papua, Kepulauan Riau, Kalimantan Barat, dan Sulawesi Utara. Batam merupakan salah Kota di wilayah Provinsi Kepulauan Riau yang merupakan tempat transit bagi imigran maupun emigran yang melewati batas negara. Mobilitas penduduk seperti itu menempatkan daerah-daerah tersebut pada keadaan berisiko tinggi terkait dengan STIs.

Lebih jauh, Situmorang dan Purwaningsih (2010) menyatakan hampir tidak ada kebijakan dan program Pemerintah Kota Batam selaku pemegang otoritas setempat untuk memerangi epidemi tersebut. Pemerintah setempat menganggap masalah tersebut bukan sesuatu yang mendesak dan perlu perhatian segera. Anggapan ini karena kurangnya pengetahuan tentang akibat HIV-AIDS terhadap kesehatan dan kesejahteraan masyarakat Batam. Selain itu, terdapat mispersepsi di antara pejabat pemerintah setempat. Ini terlihat dari masih kuatnya anggapan bahwa HIV AIDS hanyalah menginfeksi orang-orang tertentu saja yang berperilaku menyimpang.

Penanggulangan melalui program penggunaan kondom sebagai upaya preventif HIV/AIDS masih menjadi perdebatan dan program-program penanggulangan HIV/AIDS sangat menggantungkan kepada NGO dan lembaga lainnya dengan sumberdaya dan jangkauan yang terbatas. Merespon fenomena global, regional, nasional, dan lokal ini, Kabupaten Subang melaksanakan Kebijakan Pencegahan dan Penanggulangan HIV/AIDS dengan memberlakukan Peraturan Daerah Kabupaten Subang Nomor 5 Tahun 2013 tentang Pencegahan dan Penanggulangan HIV/AIDS di Kabupaten Subang. Dalam Perda tersebut dijelaskan bahwa salah satu strategi yang ditempuh adalah kemitraan-kolaboratif.

Kolaborasi pencegahan dan penanggulangan HIV/AIDS di Kabupaten Subang bersifat multiaktor yang melibatkan organisasi nonpemerintah. Hal ini mengingat kompleksnya permasalahan penanggulangan HIV/AIDS. Kondisi ini secara teoritik membutuhkan kolaborasi (Thomson, Perry, \& Miller, 2007; Agranoff, 2012), karena kolaborasi merupakan wahana penyelesaian masalah bersama yang di dalamnya terdapat proses berbagi nilai (sharing value) serta manfaat bersama (Thomson, Perry, \& Miller, 2007).

Sampai saat ini implementasi kolaborasi pencegahan dan penangulangan HIV/AIDS di Kabupaten Subang belum efektif. Hingga tahun 2017, pengidap HIV/AIDS ini tercatat mencapai 1.686 orang dengan dominasi kelompok usia 15-49 tahun (BPS Kabupaten Subang, 2018). Angka tersebut meningkat jika dibandingkan dengan tahun 2010, yaitu sebanyak 339 orang ("17 Penderita HIV/AIDS”, 2010), tahun 2014 sebanyak 893 orang (Husaeni, 2014), dan 938 kasus pada tahun 2015 (Husaeni, 2015). Saat ini, Subang masuk dalam peringkat ke-6 kabupaten yang memiliki penderita HIV/AIDS terbanyak, dari total 26 kabupaten yang ada di Jawa Barat (Husaeni, 2014).

Secara teoritik, kolaborasi sebagai jaringan kerja antarorganisasi pemerintah dan nonpemerintah merupakan babak baru dalam perkembangan administrasi publik yang mengarah pada governance models, yang sebelumnya didominasi oleh birokrasi pemerintah. Hal tersebut dinyatakan Eggers (dalam Wanna \& O'Flynn, 2008) sebagai berikut:

"In the twentieth century, hierarchical government bureaucracy was the predominant organisational model used to deliver public services and fulfill public-policy goals. Public managers won acclaim by ordering those under them to accomplish highly routine, tasks with uniformity but without discretion".

Pemerintahan dengan birokrasi klasik saat ini dihadapkan pada dinamika lingkungan yang dinamis. Keberadaan lembaga-lembaga publik selalu berhadaphadapan dengan kebutuhan publik yang senantiasa dinamis. Hal-hal ini yang seharusnya direspon oleh organisasi melalui perubahan sebagai sesuatu yang mutlak ditempuh, sebagaimana diungkapkan McNabb (2009):

"......public organizations and the people with whom they have contact are bound together in a common context of needs, wants, and services. When the needs of the people or the environment in 
which the government renders its services change, the organization must also change".

Kemunculan konsep kolaborasi sebagai teori interorganisasi merupakan kritik terhadap intraorganisasi. Dalam Teori interorganisasi, pemerintah bukan lagi satu-satunya aktor yang memegang monopoli dalam penanganan masalahmasalah publik. Aktor di luar pemerintah dapat terlibat bersama-sama pemerintah dalam penyelesaian masalah-masalah publik melalui keterkaitan jaringan (interorganizational networks). Salah satu langkah yang ditempuh adalah organisasi membuka diri untuk melakukan kontak dan jaringan kerja dengan organisasi lain.

Endarti (2004) menyatakan pendekatan teori interorganisasi mendasari teori maupun praktek governance, yang memandang lingkungan (di luar organisasi pemerintah) sebagai serangkaian entitas organisasi lain yang memiliki keterkaitan dan sangat berpengaruh terhadap organisasi tersebut. Penanganan masalah publik yang makin kompleks menurut Haynes (2003) memunculkan pergeseran paradigma. Dalam paradigma baru administrasi publik, pemerintah tidak lagi menjadi aktor tunggal dalam penyelesaian masalah-masalah publik. Peran dominan pemerintah dalam penyelesaian masalah-masalah publik tidak lagi relevan (Dwiyanto, 2004).

Kompleksitas permasalahan publik ini menuntut pemerintah memperluas aktivitasnya ke luar batas fungsi tradisionalnya. Dalam hal ini, Agranoff (2012) mengatakan:
"Although at one time collaboration referred to the cross-functional effort of persons working within agencies, it now also refers to those who cross the boundaries of organized entities working in dyadic, triadic, or networked relationships that are transactional in nature. Similarly, at one time management referred to the activity of strategy and direction given to single organizations, whereas today collaborative management refers to similar activities that reach across levels of government and across organizations. Thus, collaborative management is a concept that describes the process of facilitating and operating in multiorganizational arrangements to solve problems that cannot be solved, or solved easily, by single organizations"

Aktivitas yang melintasi batas-batas organisasi pemerintah ini menuntut lembaga birokrasi menjalin relasi dengan lembaga non pemerintah melalui proses tawar-menawar kepentingan, negosiasi, menjalin kesepakatan, membentuk kemitraan formal untuk selanjutnya melakukan perubahan ke arah pola kerja multiagency (Agranoff, 2012). Adanya keterlibatan pihak di luar pemerintah ini menunjukkan praktek administrasi publik sudah menganut nilai-nilai governanve, sebuah sistem administrasi yang melibatkan banyak pelaku (multistakeholders), baik dari pemerintah maupun dari luar pemerintah (Ansell \& Gash, 2007; Dwiyanto, 2003).

Istilah kolaborasi sebagai salah satu governance awalnya muncul pada abad ke-19 di lingkungan industri, saat memasuki masa ketika format organisasi menjadi lebih kompleks yang menuntut pembagian tugas dan penyebaran tenaga kerja lebih rumit (Wanna \& O’Flynn 2008). Kolaborasi dilihat dari aspek proses dapat dikatakan sebagai bentuk pengembangan dari kerjasama (cooperation) dan koordinasi. Dari tiga terminologi tersebut muncul satu kata kunci, yaitu sinergi di antara para aktor yang terlibat untuk menyelesaikan masalah tertentu.

Namun, terdapat perbedaan mendasar di antara ketiga terminologi tersebut. Shergold (2018) menyebut perbedaan tersebut dari pendekatan transformasi proses yang menyebutkan bahwa koordinasi lebih merupakan proses kolektif dalam pengambilan keputusan yang berkaitan dengan keikutsertaan kelembagaan, cooperation sebagai sebuah proses berbagi gagasan dan sumber daya untuk memperoleh keuntungan bersama, dan kolaborasi sebagai proses berbagi kreasi dimana terjadi upaya fasilitasi yang menjembatani lembagalembaga yang memiliki otonomi tersendiri.

Sementara itu, Thomson (2006) menyatakan terdapat sebuah konsep yang hampir sama dengan cooperation maupun koordinasi, namun maknanya lebih dalam yaitu kolaborasi, dalam bentuk integrasi, interaksi, kekuatan komitmen serta kompleksitas yang dihadapi. Lebih lanjut Thomson menjelaskan bahwa tindakan bersama (collective action) dalam bentuk kombinasi saling bertukar sumber daya dan saling menguntungkan akan mengarah pada penerapan proses kolaborasi.

Menurut Gajda (2004), terminologi kolaborasi memiliki makna yang sangat luas, tidak hanya terbatas 
pada tata hubungan antar organisasi semata. Bahkan, menurutnya, dari istilah kolaborasi inilah muncul pula terminologi-terminologi yang merujuk pada jaringan kerja antar organisasi, antara lain : joint ventures, consolidations, networks, partnerships, coalitions, collaboratives, alliances, consortiums, associations, conglomerates, councils, task forces, dan groups.

Dari adanya aspek tersebut sejumlah ahli mendifinisikan kolaborasi dari berbagai sudut pandang. Thomson, Perry, \& Miller (2007) mendefinisikan kolaborasi sebagai berikut :

"Collaboration is a process in which autonomous or semi-autonomous actors interact through formal and informal negotiation, jointly creating rules and structures governing their relationships and ways to act or decide on the issues that brought them together; it is a process involving shared norms and mutually beneficial interactions".

Berdasarkan definisi tersebut dapat disimpulkan bahwa kolaborasi merupakan upaya bersama yang memiliki aspek multidimesional. Pertama, terdapat keterlibatan dua atau lebih aktor yang tidak harus selamanya memiliki otonomi penuh. Kedua, terdapat interaksi formal maupun informal melalui upaya negosiasi di antara para partisipan. Ketiga, bentuk kerjasama yang terjalin dalam suatu jaringan kerja berlangsung pada suatu struktur hubungan yang menjadi wahana bagi mereka untuk menyelesaikan permasalahan bersama. Keempat, dalam kerjasama yang terjalin berlangsung sebuah proses yang ditandai oleh adanya upaya berbagi nilai serta manfaat bersama. Terdapat sejumlah faktor yang dapat menjadi penentu kinerja kolaborasi, kendati ditemui beberapa perbedaan sudut pandang tentang cara menentukan dan mengukur kolaborasi di antara para praktisi, baik yang berlatar belakang birokrasi, swasta, bahkan dari lembaga pemberi donor (Thomson, Perry, \& Miller, 2007).

Prefontaine, Richard, Sicotte, Turcotte, \& Dawes (2000) menyatakan bahwa keberhasilan sebuah usaha kolaborasi, khususnya dalam pemberian pelayanan sektor publik ditentukan oleh sejumlah elemen yang diistilahkan sebagai "dimensi”. Dimensi yang pertama adalah dimensi makro, meliputi lingkungan politik, sosial, ekonomi, dan budaya. Kedua, dimensi meso yaitu dimensi lingkungan institusional, bisnis, dan teknologi. Ketiga, dimensi mikro yaitu karakteristik dan tujuan mitra kerja. Dimensi mikro mencakup dasardasar bagi terbentuknya kecocokan dan kelengkapan dari bentuk kemitraan yang dijalin dengan memfokuskan diri pada faktor tujuan dan motivasi serta karakteristik masing-masing mitra kolaborasi. Keempat adalah dimensi proses kolaborasi. Pada dasarnya proses kolaborasi ditempuh melalui upaya yang didasarkan pada kondisi-kondisi spesifik untuk menjamin keberhasilan bersama melalui sejumlah tahap.

Sementara itu Thomson, Perry, \& Miller (2007) menawarkan kerangka teoritis untuk menentukan serta mengeksplorasi kolaborasi melalui lima dimensi. Pertama, governance, dimana partisipan yang terlibat dalam kolaborasi harus memahami cara terlibat dalam pengambilan keputusan yang akan mengatur perilaku dan relasi-relasi yang akan berlangsung. Kedua, administrasi, berupa struktur administratif yang berkaitan dengan aspek institusional dan implementasi praktis ke arah pada tujuan yang akan diraih. Ketiga, otonomi organisasi, yang menuntut organisasi yang bergabung berbagi nilai dengan organisasi lain. Otoritas organisasi dalam konteks ini harus "mengalah" pada kepentingan jangka panjang dengan cara berbagi otoritas organisasi lainnya. Dimensi keempat adalah mutualitas, yang memiliki makna hubungan saling ketergantungan dimana organisasi yang melakukan kolaborasi menjadi pihak yang memperoleh manfaat dari adanya ketergantungan yang berlangsung pada dinamika kepentingan dalam kelompok. Norma merupakan dimensi kelima berupa asas resiprositas atau timbal balik dan saling percaya sebagai dua konsep yang saling bersinggungan maknanya yang ditunjukkan dengan mentalitas atas kesamaan perasaan dan kewajiban. Dalam dimensi norma, saling percaya merupakan komponen terpenting kolaborasi karena dapat mereduksi kompleksitas dan biaya transaksi sebagaimana sering tampak pada format organisasi lain.

Penelitian-penelitian kerjasama antaraktor dengan pendekatan kolaborasi dalam pencegahan dan penanggulangan HIV/AIDS belum banyak dilakukan. Penelitian-penelitian umumnya mengangkat masalah pemeliharaaan kesehatan, penanggulangan, epidemi dan masalah sosial lainnya seperti stigma atas ODHA dan peran keluarga dalam mengatasi penyebaran dan penularan HIV/AIDS. Suryaningdiah (2016), misalnya, meneliti tentang bagaimana meningkatkan kepatuhan 
pengobatan ARV pasien dengan meningkatkan motivasi untuk mengambil obat, intervensi dan dukungan keluarga pasien, serta sistem keperawatan dan kepuasan layanan dengan pelayanan prima serta monitoring kepatuhan. Biello, Grinsztejn, Fernandes, Edeza, Kamel, ..., \& Mimiaga (2019) meneliti program pengobatan komprehensif kepatuhan ART remaja di Brasil menemukan bahwa hambatan sosial atas kepatuhan berasal hambatan individu (pengetahuan yang rendah), hambatan antarpribadi seperti stigma, dan hambatan struktural seperti akses transportasi serta pengobatan.

Masalah epidemi HIV/AIDS diangkat oleh Nyoko, Hara, \& Abselian (2016) di Provinsi Nusatenggara Timur yang terus meningkat setiap tahun, dimana $97,7 \%$ infeksi melalui hubungan seksual. Heriana, Nurjannah, \& Suparman (2018) mengemukakan sisi lain tentang pariwisata sebagai determinan prostitusi yang dapat meningkatan prevalensi HIV/AIDS, karena prostitusi merupakan daya tarik yang ditawarkan industri pariwisata.

Murtono, Riyanto, \& Shaluhiyah (2018) berbicara tentang faktor yang berpengaruh terhadap kejadian HIV/AIDS. Temuannya adalah perilaku pemakaian kondom yang tidak konsisten, riwayat IMS, dan aktivitas seks merupakan kombinasi faktor-faktor yang berpengaruh. Selanjutnya, Marsito dan Saraswati (2016) menyatakan keluarga berperan penting dalam mendidik remaja menghindari penyimpangan perilaku seksual. Ada korelasi positif fungsi kesehatan keluarga terhadap pencegahan penularan HIV/AIDS.

Dampak HIV/AIDS yang sudah memprihatinkan dan akan mempengaruhi struktur demografi, sistem perawatan, dan sosial ekonomi diangkat oleh Handayani (2017). Cara penanggulangan yang disarankan adalah memperkuat kualitas pelayanan, jaminan ketersediaan obat, penghapusan stigma, serta melibatkan banyak pihak dalam pencegahannya.

Hal yang sama dikemukakan oleh Martin, Rosenberg, \& Holtgrave (2018) yang menganalisis ekonomi dan kebijakan dalam menghitung beban epidemi HIV serta memberi informasi cara terbaik menerapkan intervensi dan kebijakan untuk memaksimalkan perawatan HIV serta mengurangi penularan. Ada lima bidang penerapan kebijakan HIV, yaitu (1) menetapkan tujuan yang terukur untuk menciptakan visi dan memantau kemajuan, (2) mengambil pendekatan kesehatan dan kesejahteraan untuk mencapai tujuan-pengaturan, (3) menggunakan matriks dampak untuk menginformasikan analisis kuantitatif untuk secara eksplisit mengatasi kesenjangan kesehatan, (4) melakukan analisis dampak anggaran untuk memproyeksikan biaya dan manfaat program tahunan, serta (5) memajukan agenda penelitian sistem dan layanan kesehatan masyarakat.

Shaluhiyah, Musthofa, \& Widjanarko (2015) mengemukakan bahwa stigma terhadap ODHA yang dipengaruhi oleh sikap keluarga, tetangga, dan tokoh masyarakat menjadi sumber timbulnya persepsi tertentu (stigma) terhadap ODHA, merupakan faktor yang paling berpengaruh. Hal yang berbeda dikemukakan oleh Haryanti dan Wartini (2019) bahwa stigma yang diberikan oleh orang-orang terhadap ODHA dipengaruhi oleh faktor umur dan pendidikan dengan faktor pendidikan yang memberi pengaruh lebih besar. Temuan yang hampir sama dikemukakan oleh Kambu, Waluyo, \& Kuntarti (2016) tentang faktor umur yang paling mempengaruhi tindakan pencegahan penularan HIV oleh ODHA.

Stigma merupakan faktor yang menghambat pencegahan dan penanggulangan HIV/AIDS. Latifa dan Purwaningsih (2011) menyatakan bahwa stigma dan diskriminasi terhadap ODHA sulit dihilangkan. HIV dan AIDS dianggap sebagai penyakit kutukan tuhan karena perilaku negatif dari orang-orang yang terinfeksi. Diperlukan peran masyarakat madani untuk membuka dialog mengenai HIV/AIDS untuk menghilangkan mitos yang mendiskriminasi ODHA.

Sementara Sistiarini, Hariyadi, Munasib, \& Sari (2018) menyatakan bahwa peran keluarga belum optimal dalam pencegahan karena dalam hal ini suami maupun istri belum secara maksimal melakukan pencegahan. Istri tidak memiliki kontrol terhadap suami atas perilaku seksualnya di luar rumah. Hal ini salah satunya karena belum optimalnya pendidikan kesehatan dalam mencegah HIV/AIDS.

Aggleton, Bhana, Clarke, Crewe, Race, \& Yankah (2018) berbicara tentang pendidikan sebagai salah satu 
upaya pencegahan, pengobatan dan perawatan HIV dengan melibatkan organisasi masyarakat dan media sosial memgembangkan bentuk-bentuk Pendidikan HIV yang lebih relevan dan terpercaya. Hal yang hampir sama dikemukakan oleh Rahayu dan Rismawanti (2017) tentang tingkat pengetahuan HIV/AIDS dengan perilaku seksual pra-nikah pelajar. Hasil penelitian menunjukkan rendahnya pengetahuan tentang HIV/AIDS dapat meningkatkan kerentanan remaja tertular. Namun penelitian ini juga menemukan bahwa semakin baik pengetahuan tentang HIV/AIDS, semakin besar sikap tidak mendukung (menolak) perilaku seksual pranikah.

Pinto, Witte, Filippone, Choi, \& Wall (2018) melakukan permodelan struktural tentang perawatan HIV berkelanjutan melalui penelitian efek kolaborasi antarprofessional, (IPC) dan psiko-edukasi preexposure prophylaxis (PrEP). Dengan analisis multivariat, hasilnya menunjukkan bahwa efek IPC lebih tinggi berkaitan dan seringnya psikoedukasi. Ada pengaruh faktor-faktor spesifik bidang-bidang untuk intervensi dan kebijakan untuk meningkatkan akses pasien ke perawatan HIV berkelanjutan.

Penelitian yang sedikit terkait dengan penelitian ini adalah penelitian Isni (2016) dengan temuannya bahwa upaya untuk menghindarkan penularan HIV/AIDS oleh ibu ODHA melalui dukungan keluarga dan perilaku ibu ODHA kurang signifikan, sementara dukungan terbesar justru datang dari petugas kesehatan. Penelitian lain yang memiliki kemiripan dengan artikel ini dikemukakan oleh Shapatava, Rios, Shelley, Milan Jr, Smith, \& Uhl (2018) tentang peran organisasi berbasis kemasyarakatan yang menyediakan layanan pencegahan AID di Amerika Serikat, khususnya bagian selatan dengan pembangunan kapasitas layanan klinis dan kemitraan lintas kelembagaan.

Dengan memanfaatkan kelebihan Organisasi Berbasis Kemasyarakatan (OBK) atau Community Base Organization (CBO) dalam ketrampilannya dan hubungan masyarakat, program ini efektif meningkatkan kesehatan ODHA, namun menemui hambatan dalam pendanaan. Disarankan organisasi layanan kesehatan lain memanfaatkan keberadaan OBK atau CBO dengan bermitra.
Masalah keterpaduan dan kerjasama dikemukakan oleh Valdiserri (2018) yang menyatakan bahwa strategi nasional HIV/AIDS di USA membutuhkan sistem kesehatan terpadu, tidak terbatas pada strategi pencegahan monolitik, tetapi pencegahan dan perawatan HIV ke arah sistem kesehatan berbasis pada manusia dan mekanisme proaktif mengatasi faktorfaktor penentu sosial dan kesehatan komprehensif.

Demikian juga dengan Rhodes, Tanner, Mann-Jackson, Alonzo, Horridge, ..., \& Nall (2018) bahwa penanganan HIV harus melibatkan masyarakat untuk meningkatkan pemahaman tentang HIV dan mempromosikan kesehatan masyarakat. Ada Sembilan tema model penelitian ini, diantaranya kemitraan multisektoral, pembagian kekuasaan, berbagi informasi hasil-hasil temuan.

Terkait dengan kebijakan dan pengawasan Valdisseri dan Sullivan (2018) menggambarkan pengawasan melalui visualisasi data terkait akan mendukung promosi praktik kesehatan masyarakat yang sehat dengan mendukung tiga fungsi inti kesehatan masyarakat, yakni penilaian, pengembangan kebijakan, dan jaminan. Penggunaan data di luar khalayak dan tempat-tempat kesehatan masyarakat tradisional, akan memupuk "budaya kesehatan". Laporan tentang bagaimana data dari AIDS telah digunakan untuk mendidik dan memberdayakan masyarakat mengenai HIV dan konsekuensinya dan menargetkan intervensi HIV yang lebih baik untuk menjangkau populasi yang kurang terlayani dan rentan.

Selanjutnya penelitian Demartoto (2015) yang menggunakan pendekatan tata kelola kolaboratif dengan mengukur efektivitas collaborative governance antarpemangku kepentingan dalam pelayanan komprehensif berkesinambungan untuk menanggulangi HIV/AIDS di Kota Surakarta. Hasil penelitian menunjukkan bahwa pemberi dan penerima layanan berperan dalam penanggulangan HIV/AIDS sesuai tugas dan fungsinya masing-masing. Namun demikian, program pencegahan dan penjangkauan, layanan kesehatan, reduksi bahaya, dan pemberdayaan belum efektif. Hal tersebut dikarenakan komitmen terhadap tujuan dan sikap saling percaya antarpemangku kepentingan belum optimal dan petugas lapangan kurang profesional. Di samping itu, terdapat konflik laten antarpemangku kepentingan, kurang optimalnya 
koordinasi antaranggota Komisi Penanggulangan AIDS Daerah Kota Surakarta, dan rendahnya anggaran untuk penanggulangan HIV/AIDS karena HIV/AIDS belum menjadi isu prioritas dalam pembangunan daerah. Demartoto (2015) menyarankan untuk meningkatkan kualitas dan efektivitas collaborative governance antarpemangku kepentingan, harus ada norma, struktur, dan proses yang jelas dalam menanggulangi HIV/AIDS. Perbedaan penelitian ini dengan penelitian Demartoto adalah penelitian Demartoto tidak mengangkat dimensi otonomi dan mutualitas.

Penelitian yang terkait dengan pendanaan, masalah klasik dalam penanggulangan dan pencegahan AIDS/HIV dikemukakan oleh Hattis, Strydom, Gaio, \& Stover (2019) yang meneliti praktek pencegahan dengan pendekatan pendanaan di negara-negara bagian di Amerika Serikat. Ada lima poin temuan penelitian di antaranya mengenai faktor-faktor yang mempengaruhi penekanan virus HIV, yaitu (1) dana pencegahan nonfederal, (2) menghubungi pasien dan penyedia layanan untuk hubungan perawatan dan layanan mitra, (3) tindak lanjut dari laporan viral load yang tidak diterima untuk mengidentifikasi pasien yang tidak diobati, dan (4) pengawasan genotipe/fenotipe. Penekanan virus HIV dapat ditingkatkan dengan mengembalikan (atau membangun) dana pencegahan non-federal, dan dengan praktik pengawasan/ penjangkauan yang lebih standar.

Di Indonesia pendanaan penanggulangan dan pencegahan HIV/AIDS sejak tahun 2015 ditanggung dalam skema BPJS yang meliputi biaya perawatan serta pemeriksaan laboratorium penunjang dan pemeriksaan CD4 serta pemeriksaan viral load yang bertujuan untuk memantau kemajuan pengobatan (Syarifah, 2015, 1 Desember).

Felizzola, Wolfrum, Sol, Zea, Nieves-Lugo, del RíoGonzález, ... \& Weeks (2018) menyarankan untuk meningkatkan kesehatan yang berkualitas dengan model praktik transformatif untuk mengoptimalkan sumber daya manusia dan dalam pemberian layanan
HIV, khususnya untuk untuk pasien Latino. Sementara itu, Crystal, Melva, dan Carolee (2018) mengangkat aksetabilitas pencegahan HIV di kalangan penduduk asli Amerika dengan berbasis budaya penduduk asli Amerika yang masih sedikit.

\section{Metode Penelitian}

Dalam penelitian ini, analisis difokuskan pada ekplanasi relasi-relasi organisasional para aktor pada pencegahan dan penanggulangan HIV/AIDS. Tahap awal yang ditempuh adalah pengumpulan data untuk memperoleh data kuantitatif yang selanjutnya akan dianalisis dengan menggunakan Second Order Confirmatory Factor Analysis (CFA), yang merupakan salah satu alat analisis dalam Partial Least Square Structural Equation Modelling (PLS - SEM). Tujuannya adalah menentukan dimensi yang dominan mempengaruhi praktek kolaborasi antarinstitusi dalam pencegahan dan penanggulangan HIV/AIDS di Kabupaten Subang.

Berkaitan dengan sampel penelitian, dalam PLS - SEM tidak ada ketentuan mengenai jumlah sampel penelitian yang akan menjadi responden. Beberapa referensi merekomendasikan ukuran sampel (sample size) antara 30 sampai dengan 100 (Yamin \& Kurniawan, 2009; Haryono, 2017).

Dalam penelitian ini ukuran populasi penelitian adalah 88 orang, yaitu para aparatur yang terlibat dalam pencegahan dan penanggulangan HIV di Kabupaten Subang yang merepresentasikan unsur organisasi pemerintah dan para aktivis yang merepresentasikan peran lembaga non-pemerintah. Dari populasi ditetapkan sampel sebanyak 72 orang dengan cara membagi (kuota). Angka ini dipandang representatif, sehingga memiliki akurasi dalam pengambilan kesimpulan. Penelitian ini mengukur lima dimensi yang dijabarkan dalam sejumlah indikator sebagaimana diuraikan pada tabel 1 operasionalisasi konstruk penelitian sebagai berikut.

Tabel 1 Operasionalisasi Konstruk

\begin{tabular}{|l|l|l|c|} 
Konstruk & Dimensi & Indikator & Kode \\
\hline
\end{tabular}


Jaringan Kolaborasi Dalam Pencegahan ...|Sam'un Jaja Raharja \& Dede Akhmad

\begin{tabular}{|c|c|c|c|}
\hline \multirow[t]{28}{*}{ Kolaborasi } & \multirow[t]{5}{*}{ Governance } & $\begin{array}{l}\text { Keterikatan pada kesepakatan formal sebagai acuan kerja } \\
\text { sama }\end{array}$ & Go1 \\
\hline & & Kekuatan komitmen pada kesepakatan bersama & Go2 \\
\hline & & Pemahaman atas kepemilikan sumber daya bersama & Go3 \\
\hline & & Pemahaman atas keterlibatan rekan kerja & Go4 \\
\hline & & Kemampuan rekan kerja dalam penerapan solusi bersama & Go5 \\
\hline & \multirow[t]{5}{*}{ Administration } & Penggunaan komunikasi formal dalam kerja sama & Adm1 \\
\hline & & $\begin{array}{l}\text { Pemahaman peran dan tanggung jawab dalam penyelesaian } \\
\text { masalah bersama }\end{array}$ & Adm2 \\
\hline & & Penerapan pengorganisasian tugas berdasarkan kemampuan & Adm3 \\
\hline & & $\begin{array}{l}\text { Pengawasan antarorganisasi dalam penyelesaian masalah } \\
\text { bersama }\end{array}$ & Adm4 \\
\hline & & $\begin{array}{l}\text { Keberadaan otoritas eksternal dalam penyelesaian konflik } \\
\text { bersama }\end{array}$ & Adm5 \\
\hline & \multirow{6}{*}{$\begin{array}{l}\text { Organizational } \\
\text { Autonomy }\end{array}$} & Independensi dalam penerapan pola kerja & OA1 \\
\hline & & $\begin{array}{l}\text { Kecenderungan mengutamakan organisaisi asal dari pada } \\
\text { kolaborasi }\end{array}$ & OA2 \\
\hline & & Keterbukaan atas kontribusi dalam kerja sama & OA3 \\
\hline & & Integritas organisasi asal dalam berkolaborasi & OA4 \\
\hline & & Kerugian apabila keluar dari kolaborasi & OA5 \\
\hline & & Kemampuan mentransfer informasi antar partisipan & OA6 \\
\hline & \multirow[t]{7}{*}{ Mutuality } & Pengaruh cara kerja mitra dalam berkolaborasi & Mt1 \\
\hline & & Perbedaan filosofis cara kerja organisasi dari partisipan & Mt2 \\
\hline & & Kesamaan tujuan aktivitas organisiasi dari partisipan & Mt3 \\
\hline & & $\begin{array}{l}\text { Ketergantungan pada sumber daya yang dimiliki partisipan } \\
\text { lain }\end{array}$ & $\mathrm{Mt} 4$ \\
\hline & & Kemampuan mengkombinasikan sumber daya & Mt5 \\
\hline & & $\begin{array}{l}\text { Kemampuan pertisipan lain dalam mencapai pola win-win } \\
\text { solution }\end{array}$ & Mt6 \\
\hline & & Kebanggaan terlibat dalam kolaborasi & Mt7 \\
\hline & \multirow[t]{5}{*}{ Norms } & Kepercayaan pada mitra kerja & No1 \\
\hline & & Keandalan mitra kerja dalam kolaborasi & No2 \\
\hline & & Konsistensi kerja partisipan dalam kolaborasi & No3 \\
\hline & & $\begin{array}{l}\text { Kemampuan menghilangkan keragu-raguan partisipan dalam } \\
\text { kolaborasi }\end{array}$ & No4 \\
\hline & & $\begin{array}{l}\text { Kemampuan untuk menjembatani kesenjangan kemampuan } \\
\text { partisipan }\end{array}$ & No5 \\
\hline
\end{tabular}

Dalam menganalisis data statistik, penulis menggunakan $2^{\text {nd }}$ Order CFA, karena bentuk analisis ini dinilai sangat memadai dalam menganalisis model untuk melihat berfungsinya konstruk empirik (faktor) dalam sebuah model struktural. Model yang akan dievaluasi sebagai obyek alat analisis menggunakan Model Pengukuran (Measurement Model) yang diuji dalam penelitian ini sebagaimana gambar berikut.

Gambar 1. Model Pengukuran pada Penelitian 


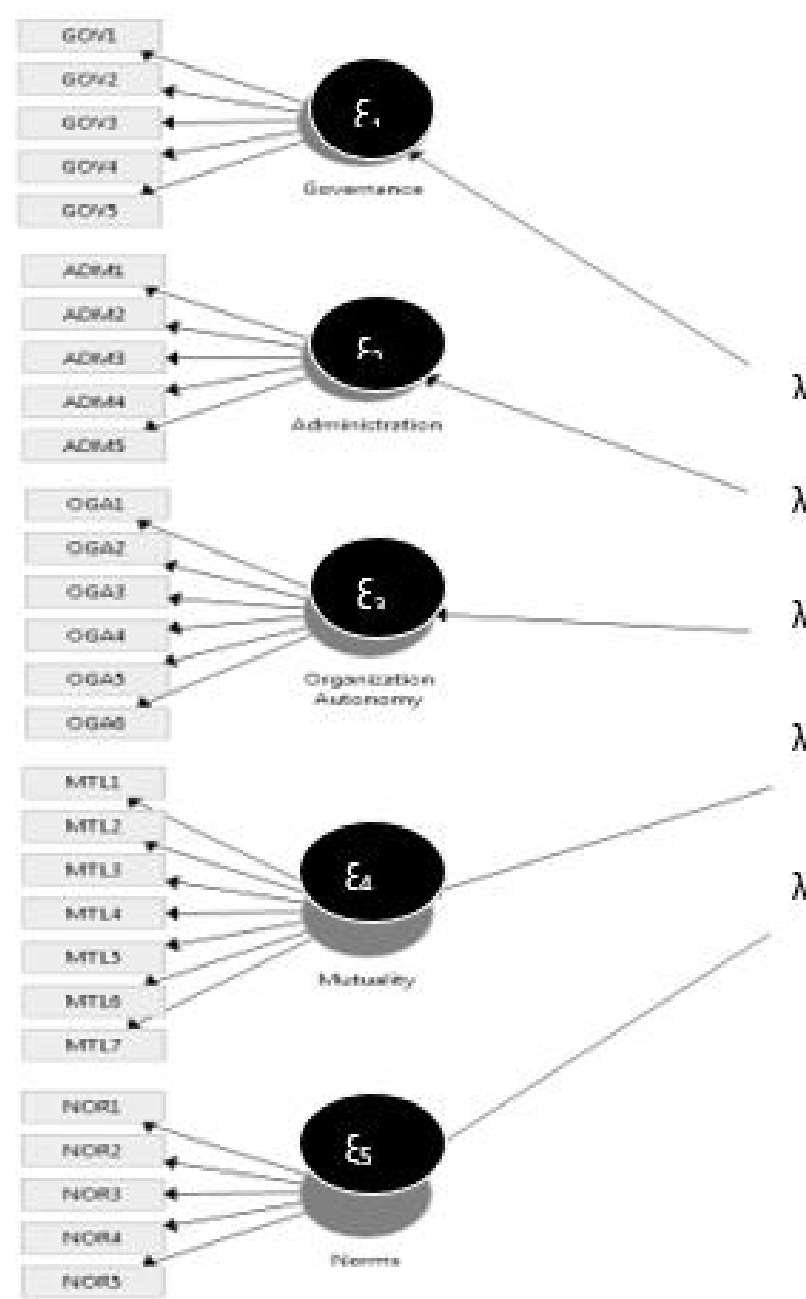

Dalam model ini dipahami hubungan antara variabelvariabel laten (tidak dapat diobservasi secara langsung). Langkah-langkah yang akan ditempuh dalam melakukan analisis ini adalah membuat matriks korelasi. Persamaan yang akan menggambarkan model pengukuran dalam penelitian ini berupa : $X=\Lambda_{x} \xi+\delta$. Berdasarkan persamaan model pengukuran dari lima dimensi ini, diharapkan akan muncul dimensi-dimensi

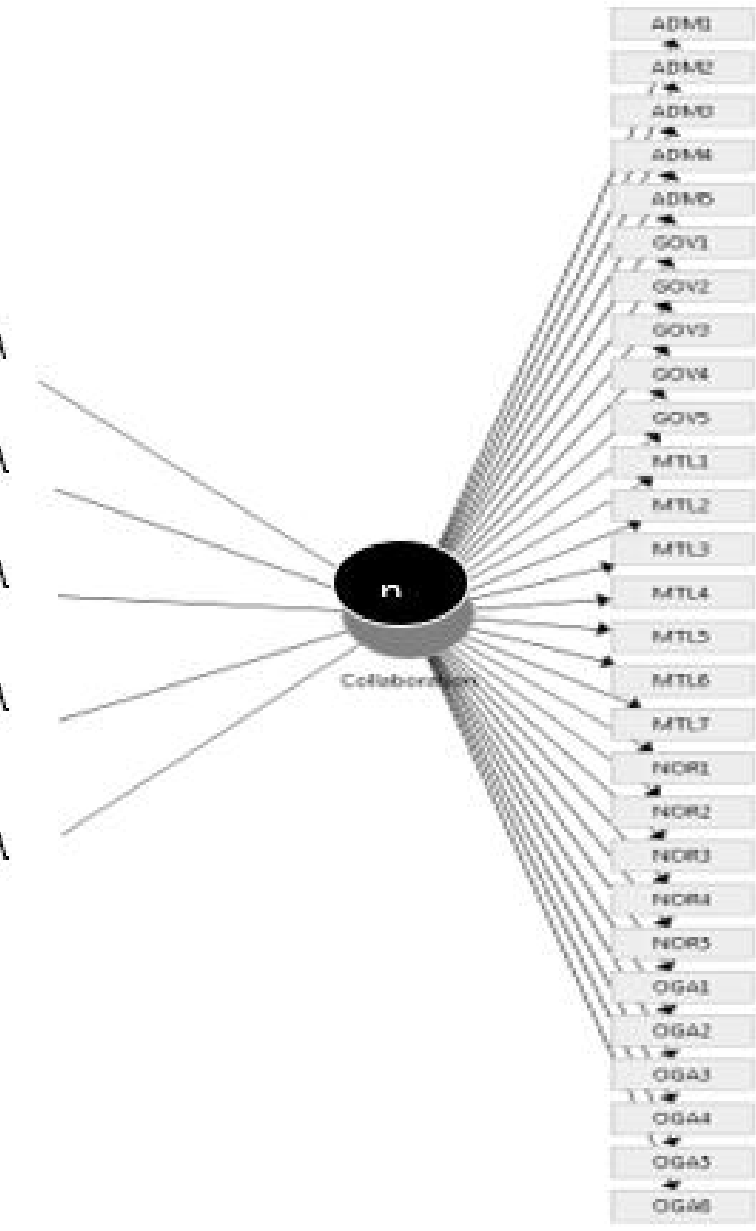

tertentu yang kontribusinya dominan terhadap variabel kolaborasi antar institusi, sehingga pertanyaan penelitian pada identifikasi masalah akan terjawab.

\section{Hasil Penelitian dan Pembahasan}

Paparan pertama hasil penelitian dan pembahasan akan diawali dengan bentuk keterlibatan partisipan dalam kolaborasi sebagaimana tabel berikut.

Tabel 2. Keterlibatan Partisipan dalam Kolaborasi Pencegahan dan Penanggulangan HIV/AIDS

\begin{tabular}{|c|c|c|c|}
\hline Partisipan & Bentuk Keterlibatan & Bentuk Implementasi & Penerima Manfaat \\
\hline $\begin{array}{l}\text { KPA Kabupaten } \\
\text { Subang }\end{array}$ & Koordinasi & $\begin{array}{l}\text { Pengamatan epidemiologi pada } \\
\text { kelompok penduduk yang beresiko } \\
\text { tinggi tertular dan menjadi } \\
\text { penular/penyebar AIDS. } \\
\text { Penyuluhan bahaya dan cara } \\
\text { pencegahan AIDS bagi masyarakat. } \\
\text { Penyebarluasan informasi AIDS } \\
\text { melalui media massa. } \\
\text { Pembentukan kelompok kerja } \\
\text { penanggulangan HIV dan AIDS }\end{array}$ & $\begin{array}{l}\text { SKPD dan Lembaga } \\
\text { Non-Pemerintah }\end{array}$ \\
\hline
\end{tabular}


Jaringan Kolaborasi Dalam Pencegahan ...|Sam'un Jaja Raharja \& Dede Akhmad

\begin{tabular}{|c|c|c|c|}
\hline Partisipan & Bentuk Keterlibatan & Bentuk Implementasi & Penerima Manfaat \\
\hline Dinas Kesehatan & $\begin{array}{l}\text { Pelayanan Medis } \\
\text { (Preventif dan Kuratif) }\end{array}$ & $\begin{array}{l}\text { Pencegahan dan Penanggulangan } \\
\text { HIV } \\
\text { Pengembangan Media dan Informasi } \\
\text { Hidup Sehat }\end{array}$ & $\begin{array}{l}\text { Kelompok Terinfeksi } \\
\text { Kelompok Berisiko } \\
\text { Kelompok Rentan } \\
\text { Kelompok Umum } \\
\text { Kelompok Usia muda }\end{array}$ \\
\hline Dinas Sosial & $\begin{array}{l}\text { Diseminasi dan } \\
\text { Pemberdayaan } \\
\text { Kelompok Sasaran }\end{array}$ & $\begin{array}{l}\text { Pembinaan bagi Wanita Penjaja } \\
\text { Seksual } \\
\text { Bimbingan Teknis Pencegahan } \\
\text { Penyakit Sosial Berbasis Keluarga }\end{array}$ & $\begin{array}{l}\text { Kelompok Berisiko } \\
\text { Kelompok Rentan } \\
\text { Kelompok Umum } \\
\text { Kelompok Usia muda } \\
\end{array}$ \\
\hline $\begin{array}{l}\text { Badan Pemberdayaan } \\
\text { Masyarakat dan } \\
\text { Keluarga Berencana }\end{array}$ & $\begin{array}{l}\text { Diseminasi dan } \\
\text { Pemberdayaan } \\
\text { Kelompok Sasaran }\end{array}$ & $\begin{array}{l}\text { Advokasi dan Komunikasi, } \\
\text { Informasi dan Edukasi (KIE) tentang } \\
\text { Kesehatan Reproduksi Remaja } \\
\text { Fasilitasi forum pelayanan } \\
\text { Kesehatan Reproduksi Remaja pada } \\
\text { Kelompok Sebaya di luar sekolah } \\
\end{array}$ & $\begin{array}{l}\text { Kelompok Berisiko } \\
\text { Kelompok Rentan } \\
\text { Kelompok Umum } \\
\text { Kelompok Usia muda }\end{array}$ \\
\hline $\begin{array}{l}\text { Badan Perencanaan } \\
\text { Pembangunan Daerah }\end{array}$ & $\begin{array}{l}\text { Koordinasi pencegahan } \\
\text { dan penanggulangan } \\
\text { HIV/AIDS pada aspek } \\
\text { perumusan kebijakan }\end{array}$ & $\begin{array}{l}\text { Asistensi perencanaan tahunan yang } \\
\text { berkaitan dengan pencegahan dan } \\
\text { penanggulangan HIV/AIDS } \\
\text { Monotoring pelaksanaan program- } \\
\text { program dan kegiatan pencegahan } \\
\text { dan penanggulangan HIV/AIDS }\end{array}$ & KPA dan SKPD terkait \\
\hline Dinas Pendidikan & Fasilitasi program & $\begin{array}{l}\text { Fasilitasi kegiatan diseminasi yang } \\
\text { diselenggarakan oleh KPA dan LSM }\end{array}$ & Kelompok Usia muda \\
\hline $\begin{array}{l}\text { Dinas Tenaga Kerja } \\
\text { dan Transmigrasi }\end{array}$ & $\begin{array}{l}\text { Pembinaan, monitoring } \\
\text { dan evaluasi di sektor } \\
\text { ketenagaakerjaan }\end{array}$ & $\begin{array}{l}\text { Pengawasan serta monitoring atas } \\
\text { risiko penularan dan pemeriksaan } \\
\text { HIV/AIDS di tempat kerja sektor } \\
\text { industri dan buruh migran } \\
\text { Diseminasi pencegahan HIV/AIDS } \\
\text { bagi buruh sektor industri dan buruh } \\
\text { migran }\end{array}$ & $\begin{array}{l}\text { Kelompok Berisiko } \\
\text { Kelompok Rentan }\end{array}$ \\
\hline Dinas Perhubungan & Fasilitasi program & $\begin{array}{l}\text { Diseminasi pencegahan HIV/ AIDS } \\
\text { bagi para pengemudi angkutan } \\
\text { umum antar provinsi }\end{array}$ & $\begin{array}{l}\text { Kelompok berisiko } \\
\text { Kelompok Umum }\end{array}$ \\
\hline $\begin{array}{l}\text { Lembaga } \\
\text { Pemasyarakatan }\end{array}$ & $\begin{array}{l}\text { Pemberdayaan Warga } \\
\text { Binaan }\end{array}$ & $\begin{array}{l}\text { Fasilitasi kegiatan diseminasi yang } \\
\text { diselenggarakan oleh KPA dan LSM }\end{array}$ & $\begin{array}{l}\text { Kelompok Berisiko } \\
\text { Kelompok Rentan } \\
\text { Kelompok Umum } \\
\text { Kelompok Usia muda } \\
\end{array}$ \\
\hline $\begin{array}{l}\text { Kantor Departemen } \\
\text { Agama }\end{array}$ & Fasilitasi Program & $\begin{array}{l}\text { Fasilitasi kegiatan diseminasi yang } \\
\text { diselenggarakan oleh KPA dan LSM }\end{array}$ & $\begin{array}{l}\text { Kelompok Berisiko } \\
\text { Kelompok Rentan } \\
\text { Kelompok Umum } \\
\text { Kelompok Usia muda }\end{array}$ \\
\hline $\begin{array}{l}\text { Palang Merah } \\
\text { Indonesia }\end{array}$ & $\begin{array}{l}\text { Pencegahan } \\
\text { penyebaran virus HIV }\end{array}$ & $\begin{array}{l}\text { Pemeriksaan darah dan identifikasi } \\
\text { potensi penyebaran virus HIV }\end{array}$ & $\begin{array}{l}\text { Kelompok Berisiko } \\
\text { Kelompok Rentan } \\
\text { Kelompok Umum } \\
\text { Kelompok Usia muda } \\
\end{array}$ \\
\hline MUI & Fasilitasi Program & $\begin{array}{l}\text { Fasilitasi kegiatan diseminasi yang } \\
\text { diselenggarakan oleh KPA dan LSM }\end{array}$ & $\begin{array}{l}\text { Kelompok Berisiko } \\
\text { Kelompok Rentan } \\
\text { Kelompok Umum } \\
\text { Kelompok Usia muda } \\
\end{array}$ \\
\hline $\begin{array}{l}\text { Tim Penggerak PKK } \\
\text { Kabupaten Subang }\end{array}$ & $\begin{array}{l}\text { Pencegahan } \\
\text { penyebaran virus HIV }\end{array}$ & $\begin{array}{l}\text { Fasilitasi kegiatan diseminasi yang } \\
\text { diselenggarakan oleh KPA }\end{array}$ & $\begin{array}{l}\text { Kelompok Umum } \\
\text { Kelompok Usia muda }\end{array}$ \\
\hline Yayasan Resik & Advokasi & $\begin{array}{l}\text { Membangun jaringan kerja dengan } \\
\text { pemerintah }\end{array}$ & $\begin{array}{l}\text { Kelompok Terinfeksi } \\
\text { Kelompok Berisiko }\end{array}$ \\
\hline
\end{tabular}


Jurnal Kependudukan Indonesia | Vol. 14, No. 1, Juni 2019|29-48

\begin{tabular}{|c|c|c|c|}
\hline Partisipan & Bentuk Keterlibatan & Bentuk Implementasi & Penerima Manfaat \\
\hline & & $\begin{array}{l}\text { Advokasi program dan kasus } \\
\text { HIV/AIDS ke pemerintah } \\
\text { Memantau pelaksanaan program } \\
\text { yang dijalankan pemerintah }\end{array}$ & $\begin{array}{l}\text { Kelompok Rentan } \\
\text { Kelompok Umum } \\
\text { Kelompok Usia muda }\end{array}$ \\
\hline PKBI Cabang Subang & Advokasi & $\begin{array}{l}\text { Membangun jaringan kerja dengan } \\
\text { pemerintah } \\
\text { Advokasi program dan kasus } \\
\text { HIV/AIDS ke pemerintah } \\
\text { Memantau pelaksanaan program } \\
\text { yang dijalankan pemerintah }\end{array}$ & $\begin{array}{l}\text { Kelompok Terinfeksi } \\
\text { Kelompok Berisiko } \\
\text { Kelompok Rentan } \\
\text { Kelompok Umum } \\
\text { Kelompok Usia muda }\end{array}$ \\
\hline Himpunan Abiyasa & Advokasi & $\begin{array}{l}\text { Membangun jaringan kerja dengan } \\
\text { pemerintah } \\
\text { Advokasi program dan kasus } \\
\text { HIV/AIDS ke pemerintah } \\
\text { Memantau pelaksanaan program } \\
\text { yang dijalankan pemerintah }\end{array}$ & $\begin{array}{l}\text { Kelompok Terinfeksi } \\
\text { Kelompok Berisiko } \\
\text { Kelompok Rentan } \\
\text { Kelompok Umum } \\
\text { Kelompok Usia muda }\end{array}$ \\
\hline
\end{tabular}

Selanjutnya dipaparkan dan dianalisis konstruk kolaborasi yang diukur secara reflektif dengan menggunakan lima dimensi, yaitu governance, administrations, organizatioanl autonomy, mutuality, dan norms yang selanjutnya direfleksikan oleh 28 indikator. Hasil perhitungan untuk koefisien jalur (loading factor) dari konstruk kolaborasi terhadap dimensi dan indikatornya dalam penelitian ini menggunakan software Smart PLS versi 3 yang disajikan dalam gambar di bawah ini.

\section{Gambar 2 Diagram Jalur Model Second Order CFA Kolaborasi Pencegahan dan Penanggulangan HIV/AIDS}

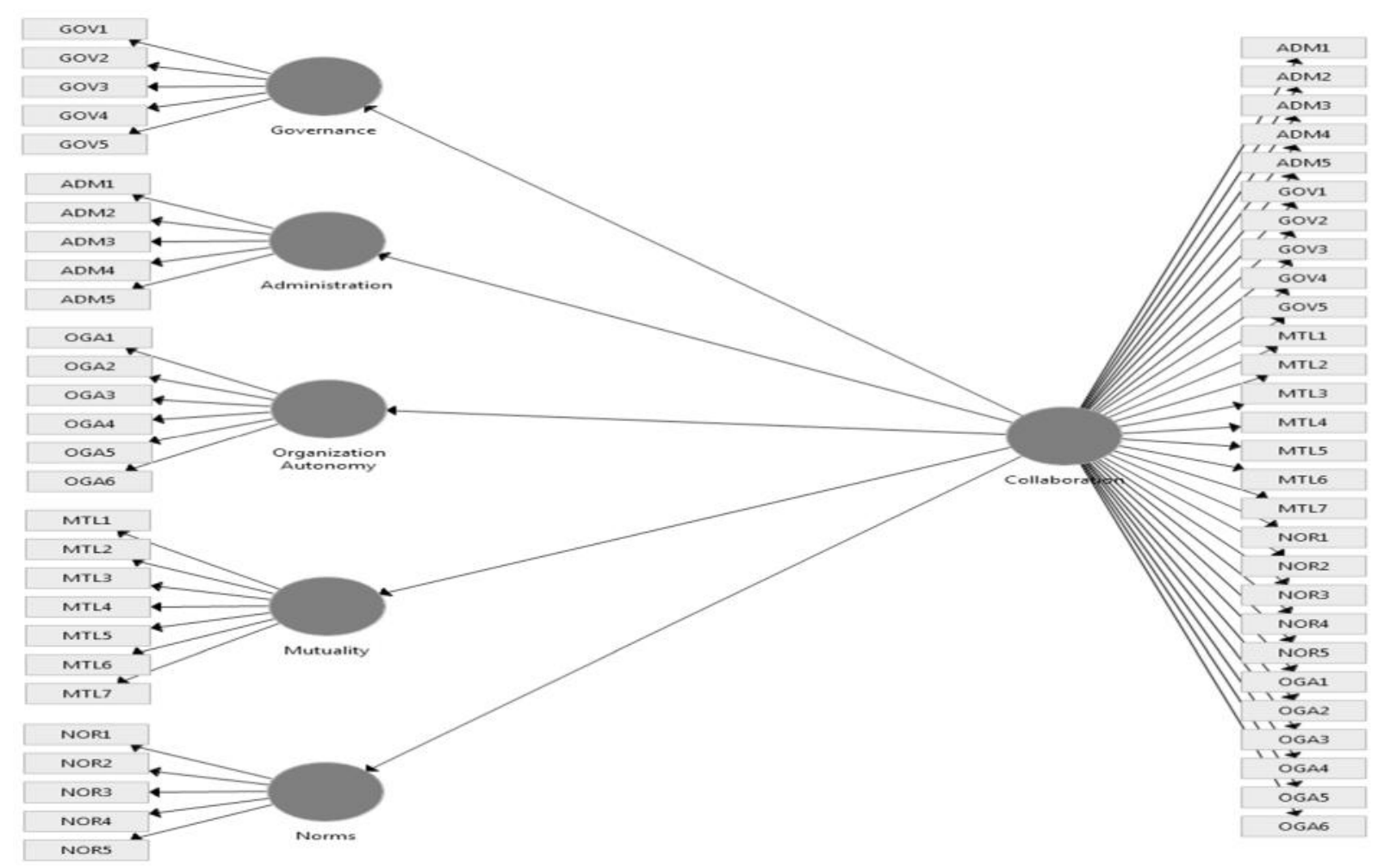

Dari diagram koefisein jalur terlihat bahwa semua dimensi pada konstruk kolaborasi memiliki loading factor $>0,5$. Besaran loading factor pada indikator di atas rule of thumb 0,50 membuktikan bahwa dimensi-dimensi pada sebuah kontruk laten dinyatakan sudah mampu menjelaskan atau merefleksikan konstruknya (Hair, 
Tabel 3. Hasil Evaluasi Model $2^{\text {nd }}$ Order CFA

\begin{tabular}{|l|c|c|c|c|c|c|c|}
\hline \multicolumn{1}{|c|}{$\begin{array}{c}\text { Konstruk/ } \\
\text { Dimensi }\end{array}$} & $\begin{array}{c}\text { Loading } \\
\text { Factor }\end{array}$ & $\begin{array}{c}\text { R- } \\
\text { Square }\end{array}$ & $\begin{array}{c}\text { Cronbach } \\
\text { Alpha }\end{array}$ & $\begin{array}{c}\text { Composite } \\
\text { Reliability }\end{array}$ & $\begin{array}{c}\text { Discriminant } \\
\text { Validity }\end{array}$ & AVE & $\begin{array}{c}\text { Pengaruh } \\
\text { terhadap Konstruk }\end{array}$ \\
\hline Collaboration & - & - & 0.957 & 0.963 & 0.688 & 0.751 & Kuat \\
\hline Governance & 0.904 & 0.82 & 0.956 & 0.956 & 0.922 & 0.851 & Kuat \\
\hline Administration & 0.885 & 0.78 & 0.953 & 0.953 & 0.917 & 0.841 & Kuat \\
\hline $\begin{array}{l}\text { Organizational } \\
\text { Autonomy }\end{array}$ & 0.898 & 0.81 & 0.802 & 0.857 & 0.709 & 0.503 & Kuat \\
\hline Mutuality & 0.749 & 0.56 & 0.920 & 0.920 & 0.791 & 0.625 & Moderat \\
\hline Norms & 0.753 & 0.57 & 0.885 & 0885 & 0.782 & 0.611 & Moderat \\
\hline
\end{tabular}

Black, Babin \& Anderson, 2010; Wong, 2013; Ghozali, 2014). Adapun ringkasan hasil analisis $2^{\text {nd }}$ Order CFA pada Konstruk Kolaborasi Pencegahan dan Penanggulangan HIV/AIDS di Kabupaten Subang dapat dilihat pada tabel 3.Terlihat dari tabel 3bahwa semua dimensi memiliki loading factor pada koefisien jalur $>0,50$, sehingga dapat dikatakan bahwa semua dimensi sudah mampu menjelaskan Konstruk Kolaborasi.

Dalam konteks ini besaran loading factor adalah nilai korelasi antara dimensi dengan konstruk latennya. Pada sejumlah referensi, bobot faktor sebesar 0,50 atau lebih dianggap memiliki validasi yang cukup kuat untuk menjelaskan konstruk laten (Hair dkk., 2010; Ghozali, 2011). Walaupun pada sebagian referensi lainnya menjelaskan bahwa loading factor paling lemah yang bisa diterima adalah 0,40 (Ferdinand, 2000). Nilai ini memiliki konstribusi yang lebih tinggi untuk menjelaskan konstruk latennya, sehingga dapat disimpulkan bahwa semua dimensi valid dalam mengukur konstruk Kolaborasi. Validitas data ini diperkuat dengan besaran discriminant validity yang angka untuk tiap dimensi juga $>0,50$.

Selanjutnya, untuk reliabilitas data dihitung dengan besaran angka cronbach alpha dan composite reliability yang besaran pada tiap dimensi $>0,70$. Rule of thumbs pada reliabilitas minimal 0.70 (Hair dkk., 2010). Namun referensi lain menyebut angka 0.60 sebagai nilai minimal untuk rule of thumbs (Black \& Champion, 2009). Kekuatan reliabilitas pada tiap diperkuat dengan besaran Average Variance Extracted (AVE) yang pada semua dimensi memiliki angka $>0.50$ sebagai syarat minimal pada rule of thumbs reliabilitas data (Ghozali, 2011:81). Dari data hasil pengolahan, kentara besaran AVE pada dimensi-dimensi yang merefleksikan konstruk kolaborasi ternyata $>0,50$.

Selain mampu menjelaskan konstruk Kolaborasi, kelima dimensi tersebut juga memiliki nilai signifikansi tinggi pada saat merefleksikan konstruk sebagaimana dapat dilihat pada diagram berikut. 


\section{Gambar 3. Diagram Jalur Signifikansi Loading Factor pada Second $2^{\text {nd }}$ Order CFA}

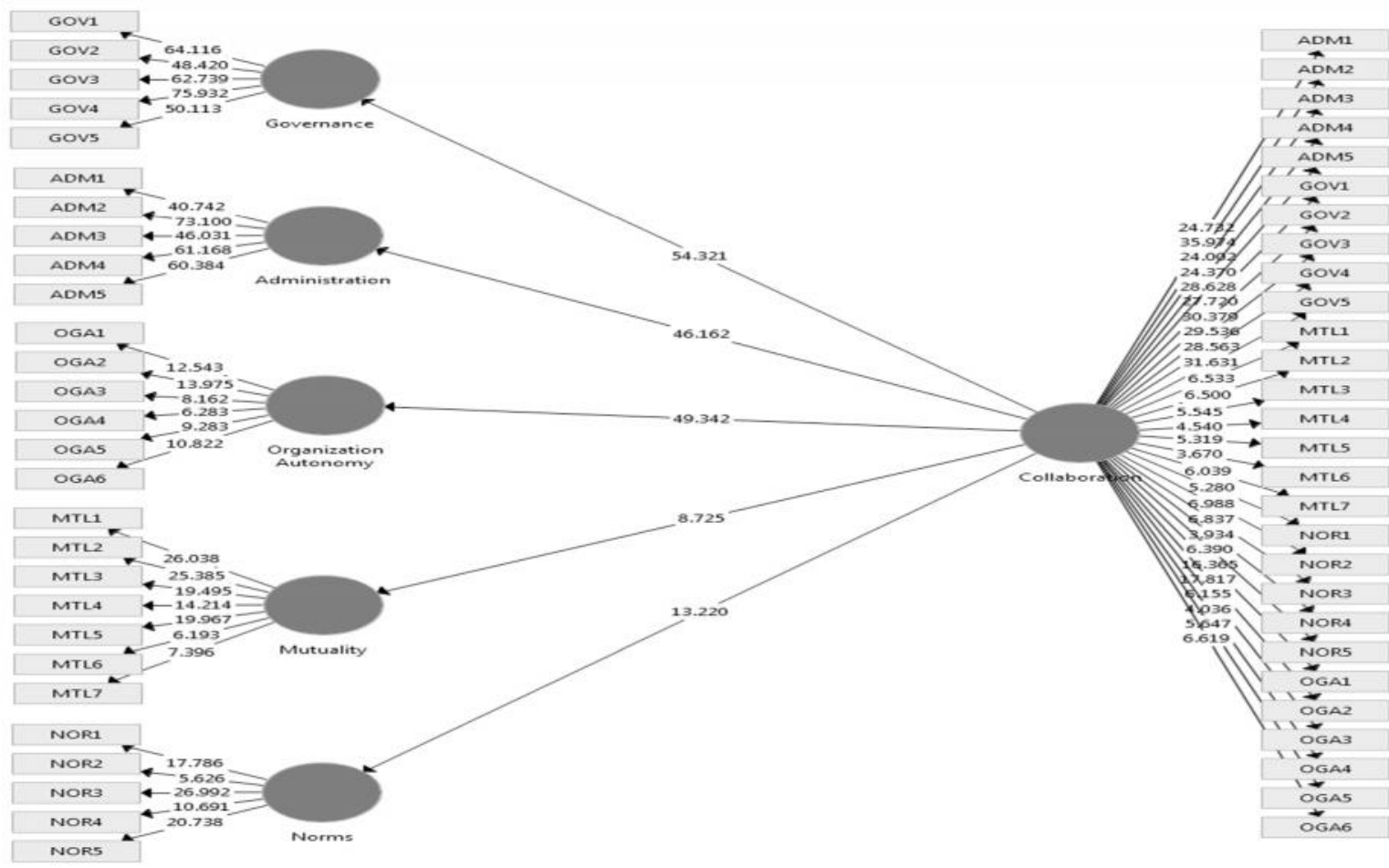

Sedangkan untuk hasil penghitungan aspek signifikansi, dapat dilihat pada tabel berikut:

Tabel 3. Hasil Analisis Bootstrapping Model $2^{\text {nd }}$ Order CFA

\begin{tabular}{|l|c|c|c|c|c|}
\hline \multicolumn{1}{|c|}{ Path } & $\begin{array}{c}\text { Original } \\
\text { Sample } \\
(\boldsymbol{O})\end{array}$ & $\begin{array}{c}\text { Sample } \\
\text { Mean } \\
(M)\end{array}$ & $\begin{array}{c}\text { Standard } \\
\text { Deviation } \\
(\text { STDEV })\end{array}$ & $\begin{array}{c}T- \\
\text { Statistics }\end{array}$ & $\begin{array}{c}P \text { - } \\
\text { Values }\end{array}$ \\
\hline Collaboration --> Administration & 0.812 & 0.804 & 0.068 & 45.152 & 0.00 \\
\hline Collaboration --> Governance & 0.720 & 0.744 & 0.069 & 50.309 & 0.00 \\
\hline Collaboration --> Mutuality & 0.576 & 0.651 & 0.098 & 8.927 & 0.00 \\
\hline Collaboration --> Norms & 0.818 & 0.805 & 0.006 & 13.024 & 0.00 \\
\hline Collaboration --> Organizational Autonomy & 0.692 & 0.729 & 0.080 & 56.988 & 0.00 \\
\hline
\end{tabular}

Berdasarkan tabel 3 terlihat bahwa nilai loading factor dan discriminant validity serta alpha cronbach dan composite reliability seluruhnya signifikan. Hal ini dikarenakan angka signifikansi nilai t-hitung (TStatistics) pada $2^{\text {nd }}$ Order CFA lebih besar dari 1,96 sebagai patokan t-tabel pada significant level atau nilai probabilitas $5 \%$.

Berdasarkan penghitungan dengan melihat besaran $r$ square, diperoleh hasil dimensi governance memiliki besaran pengaruh paling besar, dengan koefisien determinasi $82 \%$, dan menjadi faktor yang paling mampu menjelaskan atau merefleksikan konstruk kolaborasi. Tingginya kontribusi dimensi governance ini karena peluang partisipan untuk terlibat dalam kolaborasi relatif terbuka, serta diperkuat oleh Peraturan Presiden RI Nomor 75 Tahun 2006 tentang Komisi Penanggulangan AIDS dan Perda Kabupaten Subang Nomor 5 Tahun 2013 tentang Pencegahan dan Penanggulangan HIV/AIDS di Kabupaten Subang. Selain itu, terdapat keleluasaan masing-masing partisipan berkontribusi berdasarkan kemampuan sumber daya yang dimiliki dan penyelesaian konflik antarpartisipan ternyata dapat direduksi melalui komunikasi informal. 
Dimensi organizational autonomy dengan koefisein determinasi $81 \%$ dikarenakan adanya ketergantungan satu sama lain dalam berkolaborasi, terutama dalam menjangkau kelompok sasaran yang cenderung tertutup, walaupun masing-masing partisipan bekerja secara parsial dalam menjangkau. Dalam dimensi ini secara umum partisipan merasa diuntungkan dengan keterlibatan dalam kolaborasi. Jika keluar dari kolaborasi, maka kerugian partisipan yang bergerak pada aspek medis, kemungkinan berdampak pada risiko fatal pada kelompok sasaran. Sementara itu, untuk partisipan pada aspek nonmedis, kerugian kalau keluar dari kolaborasi berdampak pada pelanggaran aturan perundangan atau distorsi dari misi organisasi.

Dimensi administration dengan koefisein determinasi $78 \%$, memberikan indikasi dari konstruk kolaborasi dikarenakan menonjolnya praktik komunikasi dalam proses pengambilan keputusan, walaupun komunikasi formal yang bersifat timbal balik jarang terjadi. Selain itu, pemahaman peran dan tangung jawab dalam berkolaborasi lebih didasarkan pada tugas pokok dan fungsi serta misi organisasi. Pemahaman peran dan tanggung jawab partisipan dalam dimensi ini sebenarnya belum sepenuhnya tercurah pada permasalahan HIV/AIDS, kecuali pada Dinas Kesehatan dan unit-unit pelayanan medis di bawahnya. Implementasi dimensi ini juga didukung oleh adanya pemilahan fungsi antara medis dan nonmedis dalam kolaborasi yang berdampak pada perbedaan latar belakang dan misi masing-masing partisipan berdampak pada perbedaan sikap dan cara kerja. Perbedaan teknis diselesaikan secara individual karena sudah menjalin kontak secara informal dan sudah berlangsung lama.

Dimensi norms dengan koefisein determinasi 57\% didukung tingginya trust sebagai landasan dasar untuk berkolaborasi. Kendati partisipan dari organisasi nonpemerintah sering mempertanyakan sumber daya yang dimiliki partisipan dari birokrasi, terutama masalah finansial. Selanjutnya pada dimensi mutuality dengan koefisein determinasi sebesar 57\% karena adanya proses adaptasi. Para partisipan dengan keterbatasan sumber daya cenderung mengikuti cara kerja yang ditempuh oleh mitra kerjanya yang memiliki sumberdaya. Namun dalam dimensi ini juga ditemukan kecenderungan para partisipan organisasi pemerintah daerah bekerja dengan norma birokratis. Sementara itu, para partisipan yang berasal dari nonpemerintah cenderung bekerja dengan model fungsional.

\section{Kesimpulan}

Hasil penelitian menunjukkan lima dimensi konstruk kolaborasi secara signifikan menjelaskan fungsi kolaborasi dalam pencegahan dan penganggulangan HIV/AIDS di Kabupaten Subang. Walaupun demikian, kontribusi kelima dimensi ini tidak merata.

Dimensi governance merupakan dimensi yang paling besar kontribusinya, diikuti dimensi organizational autonomy, administration, dan mutuality. Dimensi norms merupakan dimensi yang paling kecil kontribusinya.

Penelitian ini merekomendasikan hal- hal sebagai berikut. Pertama, perlu dilakukan penguatan pada dimensi governance dengan memperkuat komitmen pemerintah daerah dalam memperluas keterlibatan berbagai pihak yang peduli terhadap pencegahan dan penanggulangan HIV/AIDS. Kedua, pada aspek administration, perlu untuk menerapkan model organisasi yang mampu mengakomodasi kepentingan partisipan. Ketiga, pada aspek organizational autonomy, perlu adanya perubahan orientasi dari rule driven ke mission driven bagi organisasi perangkat daerah yang menjadi leading sector pencegahan dan penanggulangan AIDS. Keempat, pada aspek mutually lebih mengutamakan kepentingan kolektif dibanding kepentingan masing-masing organisasi. Kelima, pada aspek norms, masing-masing organisasi saling membuka akses informasi dan komunikasi dua arah. Keenam, pada aspek leadership perlu dilakukan perubahan gaya dari gaya birokratis ke model governance

Penelitian ini memiliki beberapa keterbatasan, secara umum sebagai berikut. Pertama, penggunaan pendekatan kuantitatif yang mengeksplanasi data berdasarkan sampel bukan satu-satunya cara untuk mengetahui dinamika jejaring pencegahan dan penanggulangan HIV/AIDS. Kedua, masalah HIV/AIDS merupakan fenomena gunung es yang masih menyimpan banyak permasalahan. Karenanya masih diperlukan penelitian lain yang didasarkan pada prinsip skeptisisme atas dinamika yang terjadi dalam jejaring kolaborasi secara kualitatif. 


\section{Daftar Pustaka}

17 Penderita HIV/AIDS di Subang Meninggal (2010, 10 Januari). Nasional. tempo.co diakses dari https://nasional.tempo.co/read/219697/17penderita-hivaids-di-subang-meninggal/ full\&view $=$ okl.

Aggleton, P., Bhana, D., Clarke, D. J., Crewe, M., Race, K., \& Yankah, E. (2018). HIV education: Reflections on the past, priorities for the future. AIDS Education and Prevention, 30(3), 254-266.

Agranoff, R. 2012. Collaborating to Manage: A Primer for The Public Sector. Washington DC: Georgetown University Press.

Ansell, C. \& Alishin, G. 2007. Collaborative Governance in Theory and Practice. The Journal of Public Administration Research and Theory. Oxford University Press. Vol. 18. p. 543-571.

Azanella, L. A. (2018, 1 Desember). HIV/AIDS dalam Angka: 36,9 Juta Penderita, 25 Persen Tak Menyadarinya. Kompas.com. diakses dari https://lifestyle.kompas.com/read/2018/12/01/124 545720/hivaids-dalam-angka-369-juta-penderita25-persen-tak-menyadarinya.

Crystal, Lee., Melva, Thompson-Robinson., and Carolee, Dodge-Francis (2018) Acceptability of an Adapted HIV Prevention Intervention for Native American Adolecents. AIDS Education and Prevention, 30(1), 72-84, 2018 (C) 2018 The Guilford Press

Biello, K. B., Grinsztejn, B., Fernandes, N. M., Edeza, A., Kamel, L., Salhaney, P., Veloso, V. \& Mimiaga, M. J. (2019). Development of a Social Network-Based Intervention to Overcome Multilevel Barriers to ART Adherence Among Adolescents in Brazil. AIDS Education and Prevention, 31(2), 111-126.

Black, J. A. \& Dean J. C. 2009. Metode dan Masalah Penelitian Sosial. Bandung: Refika Aditama.

BPS Kabupaten Subang (2018) Subang Dalam Angka 2017.

Demartoto, A. (2015). Efektivitas Collaborative Governance dalam Pelayanan Komprehensif Berkesinambungan untuk Menanggulangi HIV/AIDS. Kesmas: National Public Health Journal, 9(4), 382-389.

Dwiyanto, A. (2003). Reformasi Tata Pemerintahan dan Otonomi Daerah. Yogyakarta: Pusat Studi Kependudukan dan Kebijakan, Universitas Gadjah Mada.
Dwiyanto, A. (2004). Reorientasi Ilmu Administrasi Publik: Dari Government ke Governance. Pidato Pengukuhan Jabatan Guru Besar pada Fakultas Ilmu Sosial dan Ilmu Politik Universitas Gadjah Mada di depan Rapat Terbuka Majelis Guru Besar Universitas Gadjah Mada, 21 Agustus 2004 di Yogyakarta

Endarti, E. W. 2004. Interaksi dalam Konteks New Governance. Jurnal Administrasi Publik. Vol. I. No. 1. April, hal..........

Felizzola, J., Wolfrum, S. G., Sol, C., Zea, M. C., Nieves-Lugo, K., del Río-González, A. M., Pinho, V., Funk, D., \& Weeks, K. (2018). Development and Implementation of an HIV Health Care Practice Transformation Model for Latinos. AIDS Education and Prevention, 30(6), 502-515.

Ferdinand, A. 2000. Structural Equation Modelling dalam Penelitian Manajemen. Semarang: Badan Penerbit Universitas Diponegoro.

Gajda, R. (2004). Utilizing Collaboration Theory to Evaluate Strategic Allainces. American Journal of Evaluation. Vol. 25 No. 11. pp: 65-77.

Ghozali, I (2011), Aplikasi Analisis Multivariate Dengan Program IBM SPSS 19, edisi 5 Semarang: Badan Penerbit Universitas Diponegoro

Ghozali, I. (2014). Structural Equation Modelling: Metode Alternatif dengan Partial Least Square $(P L S)$. Semarang: Badan Penerbit Universitas Diponegoro.

Hair Jr., J.F., Black, W.C., Babin, B.J. and Anderson, R.E. (2010) Multivariate Data Analysis: A Global Perspective. 7th Edition, Pearson Education, Upper Saddle River.

Handayani. (2017). Waspada Epidemi HIV-AIDS di Indonesia. Medical and Health Science Journal, 1, $1-8$.

Hari AIDS Sedunia, Momen Stop Penularan HIV: Saya Berani, Saya Sehat! (2018, 1 Desember) depkes.go.id. diakses dari http://www.depkes.go.id/article/view/1812030000 1/hari-aids-sedunia-momen-stop-penularan hivsaya-berani-saya-sehat-.html.

Haryanti, T. \& Wartini, W. (2019). Perception of People Living with HIV/AIDS on Social Stigma of HIV/AIDS in Sukoharjo District. Kesmas: National Public Health Journal, 13(3), 132-137. 
Haryono, Siswono. 2017. Metode SEM untuk Penelitian Manajemen. Jakarta: Luxma.

Hattis, R. P., Strydom, R. Y., Gaio, J., \& Stover, D. C. (2019). HIV Prevention Practices and Non-Federal Funding Among US States and Non-State Regions: A Survey of HIV/AIDS Directors. AIDS Education and Prevention, 31(1), 82-94.

Haynes, Philip. 2003. Managing Complexity in The Public Service. London: Open University Press.

Heriana, C., Nurjannah, S. N., \& Suparman, R. (2015). Distribusi Spasial dan Determinan Kejadian HIV/AIDS di Propinsi Jawa Barat Tahun 2014. Jurnal Ilmu Kesehatan Bhakti Husada: Health Sciences Journal, 4(2), 1-10.

Hoelman, M. B., Parhusip, B. T. P., Eko, S, Bahagijo, S., \& Santono, H. (2015). Panduan SDGs Untuk Pemerintah Daerah dan Pemangku Kepentingan Daerah. Jakarta: International NGO Forum on Indonesia Development.

Hugo, Graeme. (2011). Mobilitas Penduduk dan HIV/AIDS di Indonesia. Jakarta: UNAIDS Indonesia.

Hull, T. H., Sulistyaningsih, E., \&. Jones, G., W. (1998). Pelacuran di Indonesia, Sejarah dan Perkembangannya. Jakarta: Pustaka Sinar Harapan.

Husaeni, U. (2014, 1 Desember). 8 PNS di Subang Mengidap HIV/AIDS. Sindonews.com. diakses dari

https://daerah.sindonews.com/read/931364/21/8pns-di-subang-mengidap-hivaids-1417422877.

Husaeni, U. (2015, 16 April). Penderita HIV/AIDS di Subang dari Gelandangan hingga PNS. Sindonews.com. diakses dari https://daerah.sindonews.com/read/990192/21/pe nderita-hivaids-di-subang-dari-gelandanganhingga-pns-1429176548.

Huxham, C. \& Vangen, S. (2007). Doing Things Collaborativelly: Realizing the Advantage or Succumbing to Inertia. Collaborative Governance: A New Era of Public Policy in Australia? Canberra: Australia National University E Press.

Huxham, Chris. (1996). Collaboration and Collaborative advantage. In Creating Collaborative Advantage, ed. C. Huxham, 1-18. Thousand Oaks, CA: Sage.

Isni, K. (2016). Dukungan Keluarga, Dukungan Petugas Kesehatan, dan Perilaku Ibu HIV dalam
Pencegahan Penularan HIV/AIDS ke Bayi. Jurnal Kesehatan Masyarakat UNNES, 2.

Kambu, Y., Waluyo, A., \& Kuntarti, K. (2016). Umur orang dengan HIV AIDS (ODHA) berhubungan dengan tindakan pencegahan penularan HIV. Jurnal Keperawatan Indonesia, 19(3), 200-207.

Kementerian Kesehatan-Direktorat Jenderal Pencegahan dan Pengendalian Penyakit. 2018

Kementerian Perencanaan Pembangunan Nasional/Bappenas. 2017. Pedoman Penyusunan Rencana Aksi Tujuan Pembangunan Berkelanjutan. Jakarta.

Laporan Perkembangan HIV-AIDS dan infeksi Menular Seksual tahun 2017.

Latifa, A. \& Purwaningsih, S. S. (2011). Peran Masyarakat Madani dalam Mengurangi Stigma dan Diskriminasi Terhadap Penderita HIV \& AIDS. Jurnal Kependudukan Indonesia, VI (2), hal 51-76.

Lee, C., Thompson-Robinson, M., \& Dodge-Francis, C. (2018). Acceptability of an Adapted HIV Prevention Intervention for Native American Adolescents. AIDS Education and Prevention, 30(1), 72-84.

Marsito dan Saraswati, R. (2016). Kontribusi Fungsi Keluarga terhadap Pencegahan Penularan HIV AIDS pada Kalangan Remaja di Desa Sampang Sempor Kabupaten Kebumen. Jurnal Ilmiah Kesehatan Keperawatan, 12(1), 1-12

Martin, E. G., Rosenberg, E. S., \& Holtgrave, D. R. (2018). Economic and Policy Analytic Approaches to Inform the Acceleration of HIV Prevention in the United States: Future Directions for the Field. AIDS Education and Prevention, 30(3), 199-207.

McNabb, D. E. (2009). The New Face of Government: How Public Managers Are Forging a New Approach to Government. Boca Raton: CRC Press.

Murtono, D., Riyanto, P., \& Shaluhiyah, Z. (2018). Influential Host Factors to the Incidence of HIV/AIDS in Key Populations in Pati District. Kesmas: National Public Health Journal, 13(1), 17-22.

Nyoko, Y. O., Hara, M. K., \& Abselian, U. P. (2016). Karakteristik Penderita HIV/AIDS di Sumba Timur Tahun 2010-2016. Jurnal Kesehatan Primer, 1(1), 4-15. 
Peraturan Daerah Kabupaten Subang Nomor 5 Tahun 2013 tentang Pencegahan dan Penanggulangan HIV dan AIDS di Kabupaten Subang.

Peraturan Presiden Nomor 75 Tahun 2006 tentang Komisi Penanggulangan AIDS Nasional,

Pinto, R. M., Witte, S. S., Filippone, P., Choi, C. J., \& Wall, M. (2018). Interprofessional Collaboration and On-the-Job Training Improve Access to HIV Testing, HIV Primary Care, and Pre-Exposure Prophylaxis (PrEP). AIDS Education and Prevention, 30(6), 474-489.

Prapti, R. H. E. (2015). Kertas Kajian SRHR dan AGENDA 2030. Jakarta: Rutgers WPF Indonesia.

Pratikno. (2007). Manajemen Jaringan Dalam Perspektif Strukturasi. Jurnal Administrasi Kebijakan Publik, Vol.12, Nomor 1 (Mei 2008), hal. 1-19, Yogyakarta: MAP UGM.

Préfontaine, L., Ricard, L., Sicotte, H., Turcotte, D., \& Dawes, S. (2000). New Models of Collaboration for Public Service Delivery. Working Paper. Wordwide Trends. April.

Purwaningsih, S. S. \& Widayatun (2008). Perkembangan HIV dan AIDS di Indonesia: Tinjauan Sosio Demografis. Jurnal Kependudukan Indonesia, III (2), hal 75-95

Rahayu, I. \& Rismawanti, V. (2017). Hubungan Tingkat Pengetahuan tentang HIV/AIDS dengan Perilaku Seksual Pranikah Pelajar. Jurnal Endurance: Kajian Ilmiah Problema Kesehatan, 2(2), 145-150.

Rhodes, S. D., Tanner, A. E., Mann-Jackson, L., Alonzo, J., Horridge, D. N., Van Dam, C. N., \& Nall, J. (2018). Community-engaged research as an approach to expedite advances in HIV prevention, care, and treatment: A call to action. AIDS Education and Prevention, 30(3), 243-253.

Sanusi, Sri Rahayu. (2014). Mobilitas Penduduk Usia Produktif dan Penyebaran HIV/ AIDS di Indonesia Tahun 2013. Jakarta: Direktorat Analisis Dampak Kependudukan Badan Kependudukan dan Keluarga Berencana Nasional.

Shaluhiyah, Z., Musthofa, S. B., \& Widjanarko, B. (2015). Stigma masyarakat terhadap orang dengan HIV/AIDS. Kesmas: National Public Health Journal, 9(4), 333-339.

Shapatava, E., Rios, A., Shelley, G., Milan Jr, J., Smith, S., \& Uhl, G. (2018). Community-Based Organization Adaptations to the Changing HIV Prevention and Care Landscape in the Southern
United States. AIDS Education and Prevention, 30(6), 516-527.

Shergold, P. (2008). Governing through collaboration, in O'Flynn, Janine and Wanna, John (eds) 2008. Collaborative Governance A new era of public policy in Australia. ANU Press, 13-22

Sistiarani, C., Hariyadi, B., Munasib, M., \& Sari, S. M. (2018). Peran Keluarga dalam Pencegahan HIV/AIDS di Kecamatan Purwokerto Selatan. Jurnal Ilmu Keluarga \& Konsumen, 11(2), 96-107.

Situmorang, A. \& Purwaningsih, S. S. (2010) Local Government Responses to HIV and AIDS in the Border Areas: a Case Study of Batam. Journal of Indonesian Social Sciences, 3, pp 171-187.

Situmorang, A. (2006) Sex and Sexually Transmitted Infections: Experiences of Male Street Youth in Medan, Indonesia. Jurnal Kependudukan Indonesia, I (1), hal 67-80.

Skeldon, R. (2000). Population Mobility and HIV Vulnerability in South East Asia: An Assesment and Analysis. Bangkok: UNDP-South East Asia HIV and Development Project.

Sucipto dan Hartoyo, (2009). Menelusuri Kebijakan Anggaran HIV \& AIDS. Jakarta: Forum Indonesia untuk Transparansi Anggaran.

Suryaningdiah, D. (2016). Rekomendasi Upaya Peningkatan Kepatuhan Pengobatan ARV di Kota Surabaya (Disertasi Doktor, Universitas Airlangga).

Syarifah, F. (2015, 1 Desember). Pemeriksaan HIV/AIDS Ditanggung BPJS. Liputan6.com. diakses dari https://www.liputan6.com/health/read/2379129/p emeriksaan-hivaids-ditanggung-

bpjs?related=dable\&utm_expid=.9Z4i5ypGQeGi S7w9arwTvQ.1\&utm_referrer=https\%3A\%2F\%2 Fwww.google.com\%2F

Thomson, A. M. \& Perry, J. L. (1998). Can AmeriCorps build communities? Nonprofit and Voluntary Sector Quarterly 27: 399-420.

Thomson, A. M. \& Perry, J. L. (2006). Collaboration Process: Inside the Black Box. Public Administration Review. December, Academic Research Library pg.20

Thomson, A. M. (1999). AmeriCorps Organizational Networks: Six Case Studies of Indiana AmeriCorps Programs. National Service Fellows Program. Washington, DC: Report for the Corporation for National Service. 
Thomson, A. M. (2001). Collaboration: Meaning and measurement. Ph.D. thesis. Bloomington: Indiana University.

Thomson, A. M., Perry, J. L., \& Miller, T. M. (2007). Conceptualizing and Measuring Collaboration, The Journal of Public Administration Research and Theory. Oxford University Press. December 1.

Valdiserri, R. O. (2018). The evolution of HIV prevention programming: moving from intervention to system. AIDS Education and Prevention, 30(3), 187-198.

Valdiserri, R. O., \& Sullivan, P. S. (2018). Data Visualization Promotes Sound Public Health Practice: The AIDSvu Example. AIDS Education and Prevention, 30(1), 26-34.

Waluyo, A. 2011. Indonesian Nurses' HIV Knowledge, Religiosity, Individual Stigma Attitudes, and Workplace HIV-Stigma. Doctoral Thesis. Chicago: Graduate College of the University of Illinois at Chicago.

Wanna, J. and O'Flynn, J. (2008). Collaborative Governance: A New Era of Public Policy in Australia? Canberra: Australia National University E Press.

Wong, K. K. K. (2013). Partial Least Squares Structural Equation Modeling (PLS-SEM) Techniques Using SmartPLS. Marketing Bulletin. pp 1-32 Peraturan Menteri Kesehatan Republik Iindonesia Nomor 21 Tahun 2013 tentang Penanggulangan HIV dan AIDS.

Yamin, S. \& Kurniawan, H. (2009). Structural Equation Modelling. Jakarta: Salemba Infotek.

Yulianingsih, T. (2017). Penyebaran Tertinggi di Asia Pasifik, Filipina Darurat HIV/AIDS. Liputan6.com. diakses dari https://www.liputan6.com/global/read/3044459/p enyebaran-tertinggi-di-asia-pasifik-filipinadarurathivaids? related=dable\&utm expid=.9Z4i5ypGQe GiS7w9arwTvQ.1\&utm_referrer=. 
Jurnal Kependudukan Indonesia | Vol. 14, No. 1, Juni 2019|29-48 